\title{
Adsorption of Phenol on Carbon Based on Cactus and Banana Peel
}

\author{
Tossou Germain, Ekou Lynda, Ekou Tchirioua \\ Laboratoire de thermodynamique et physico-chimique des matériaux et procédés, UFR-SFA Université Nangui Abrogoua
}

Correspondence Author: Tossou Germain, Laboratoire de thermodynamique et physico-chimique des matériaux et procédés, UFR-SFA Université Nangui Abrogoua

Received date: 11 December 2018, Accepted date: 22 Janaury 2018, Online date: 29 January 2019

Copyright: $\odot 2019$ Tossou Germain $e t$ al, This is an open-access article distributed under the terms of the Creative Commons Attribution License, which permits unrestricted use, distribution, and reproduction in any medium, provided the original author and source are credited.

\begin{abstract}
Water pollution from industrial discharges can have harmful effects on the environment and health. To reduce these effects, several wastewater treatment processes, particularly physicochemical processes, are used, in particular the adsorption technique. This study uses cactus coals (ERC, AUC) and banana peels (PBC) to remove phenol in aqueous solution. Experimental results of the influence of different parameters showed that adsorption increases with time and reaches equilibrium at 90 minutes. The adsorption is maximal at acidic $\mathrm{pH}$ and decreases from 2.93 to $1 \mathrm{mg} / \mathrm{g}$ for ERC, then from 2.27 to $1.19 \mathrm{mg} / \mathrm{g}$ for AUC and finally from 2.19 to $1 \mathrm{mg} / \mathrm{g}$ for PBC in the range of pH 2-12. These results indicate that ERC adsorbs phenol more.
\end{abstract}

Key words: Heavy metals, Road deposited sediments, Geo-statistical analysis, Nigeria, Atomic Absorption Spectroscopy.

\section{INTRODUCTION}

Water pollution has been a serious problem for environmental and water users. These hazardous pollutants have a remarkable ecological effect on ecosystem and posed major threat to the aquatic lives (Pan and Kurumada, 2008). Phenol, a colourless-towhite solid with a characteristic odour, is the simplest monatomic phenol, soluble in water and organic solvents (Duan et al., 2018). Pollutants containing phenol are released from many different anthropogenic sources such as petroleum refinery, pesticide manufacturing plants, petrochemicals, organic chemical manufacture (Acosta et al., 2018). This pollutant penetrates ecosystems as the result of drainage off the municipal or industrial sewage to surface water. By Natural Sources; Phenol is a constituent of coal tar, and is formed during decomposition of organic materials (Chandana and Sridevi, 2009). Increased environmental levels may result from forest fires. Phenol is toxic and some is known or suspected carcinogens (Ry and Murugesan, 2002). The presence of phenol in drinking water and irrigation water represents a serious health hazards to humans, animals, plants and microorganisms (ATSDR, 2007). Ingestion of phenol for a prolonged period of time causes mouth sore, diarrhea, excretion of dark urine and impaired vision at concentrations levels ranging between 10 and $240 \mathrm{mg} / \mathrm{L}$ (Álvarez-Torrellas et al 2017). The treatment of thise pollutants in multi-component system is complex and required effective purification processes (Han and al., 2006, Achak and al., 2009). To protect our environment from pollutants, it can be achieved either by minimizing the introduction of pollutants into the environment or by their removal from contaminated media. Several methods have been used for the removal of these polluant including chemical oxidation with ozone (Matta and al., 2008), photo degradation (Lv et al., 2011), Fenton degradation (Pourata and al., 2009), biological degradation (Moussavi and al., 2009), ozonation (Maldonado and al., 2006), membrane filtration (Banasiak and $a l ., 2011$ ) and adsorption (Al-Muhtase and al., 2011). Adsorption remains the most used and easy to implement techniques. Lignocellulosic biomass obtained from wastes and by-products ofcrops and fruit production are considered as attractive precursors for the preparation of activated carbons (Mohamed and al., 2010). Transformation of biomass obtained from these materials may show high performance in adsorption processes and surface reactivity. This adsorbent offers goodversatility and flexibility to modify its physical and chemical properties. Banana, a tropical fruit, is widely cultivated over 130 countries worldwide.

As part of this work three adsorbents have retained our attention; banana skin and two different kinds of cactus. In Ivory Cost, banana is massively cultivated and can be consumed in the fresh form and $80 \%$ of ripe banana is processed and is ingredient in many types of food such as baby food, banana streamed pastry, deep fried banana, sun-dried banana, sweet banana crisp, and banana stirs. In general banana peel was abandoned as a solid waste. 
The cactus is a tree native to the arid and semi-arid regions of Mexico. It belongs to the genus Opuntia; it is a succulent xerophytic plant capable of storing a large quantity of water and presenting no danger to human health (Habibi Y, 2004). It also has considerable values in the fields of cosmetics, medicine and food (Arba and al., 2000, Boujghagh. and Chajia, 2001). Cactus has great water retention capacity; this is due to mucilage water retention by implying coagulation properties (de Souza et al., 2014). In recent years a lot of research is invested in the field of wastewater decontamination, in particular the biosorption of heavy metals and the elemination of turbidity.

In this work, we report the preparation of banana peel and cactus support for the removal of phenol in order to develop new materials capable of reducing these environmental problems. The effects of various operating parameters on biosorption, such as contact time, initial $\mathrm{pH}$, sorbent dose, and initial solution temperature were monitored and optimal experimental conditions were determined.

\section{MATERIALS AND METHODS}

\subsection{Preparation of carbon support}

In order to valorize abundant agricultural waste, three coals from two different species of cactus and banana peels are proposed for the retention of phenol. These are carbon from Agave Utahensis (AUC), Euphorbia Resinifira (ERC) and local banana peel (PBC).

The banana peels and cactus used as raw material in this work were manually selected, exhaustively washed with distilled water until the $\mathrm{pH}$ is constant to remove soluble impurities and finally dried at room temperature $105^{\circ} \mathrm{C}$. Charring was done in a muffle furnace at $550^{\circ} \mathrm{C}$, with a ramp rate of $10^{\circ} \mathrm{C} / \mathrm{min}$; for 1 hour. The resulting carbons were stored in a desiccator for use in adsorption experiments.

\subsection{Preparation of solutions}

The commercial phenol used (99\%, MERCK) did not undergo any prior treatment. All solutions for each procedure were prepared by diluting with ultra pure water. The $\mathrm{pH}$ of the solutions is adjusted with nitric acid $\left(\mathrm{HNO}_{3}\right)$ and sodium hydroxide $(\mathrm{NaOH})$, while measuring these values using a HANNA brand $\mathrm{pH}$-meter.

\subsection{Experimental procedure}

The samples were analyzed using a UV/Vis spectrophotometer (WFJ-752) at its maximum wavelength of $510 \mathrm{~nm}$.

\subsubsection{Effect of contact time}

In order to study the effect of the contact time, an amount of $1 \mathrm{~g}$ of calcined carbons was added to $100 \mathrm{ml}$ of phenol solution $\mathrm{C}=14 \mathrm{mg} / \mathrm{L}$. The samples were taken at 20-180 min. The flasks were stirred at room temperature. After equilibrium, the adsorbent was separated from the solution by filtration. The samples were analyzed by spectrophotometer.

\subsubsection{Effect of adsorbent dosage}

The effect of adsorbent dosing on phenol adsorption was studied. several quantities of adsorbents were tested in which masses between 0.5 and $3 \mathrm{~g}$ were placed in a solution of $100 \mathrm{~mL}$ of phenol $(14 \mathrm{mg} / \mathrm{L}$ at $\mathrm{pH}=6.8$ and the suspensions were stirred at room temperature $25^{\circ} \mathrm{C}$ for $120 \mathrm{~min}$ ).

\subsubsection{Effect of pH of the solution}

The degree of ionization of the phenolic ions in aqueous solution and the surface charge of the absorbents are strongly influenced by the $\mathrm{pH}$ solution. The effect of the $\mathrm{pH}$ of the phenol adsorption solution by calcined carbons was studied by varying the initial $\mathrm{pH}$ of the $\mathrm{pH}$ solutions from 2 to 12. This end was adjusted using $\mathrm{HCl}$ or $\mathrm{NaOH}$ before the adsorbent was added and measured with a HANNA HI $99301 \mathrm{pH}$ meter.

The initial phenol concentration was set at $14 \mathrm{mg} / \mathrm{L}$. An amount of calcined carbon $(1 \mathrm{~g})$ was incubated by stirring for 90 min in $100 \mathrm{ml}$ phenol solution. After equilibrium, the suspension was filtered to separate the liquid and solid phases. The residual phenol concentration was measured spectrophotometrically at $510 \mathrm{~nm}$ using the 4-amino-antipyrine method.

\subsubsection{Effect of concentration}

Batch experiments were carried out to study the adsorption of phenol on banana and cactus carriers. Adsorption experiments were performed in Erlenmyer flasks $(250 \mathrm{~mL})$ containing $100 \mathrm{~mL}$ of phenol solution at a concentration of $1 \mathrm{to} 12 \mathrm{mg} / \mathrm{L}$. $1 \mathrm{~g}$ of calcined carbon was added and the mixture stirred for 90 minutes. After filtration, the solutions were filtered and analyzed.

\subsubsection{Effect of temperature}

The effect of temperature on phenol absorption was studied at different temperatures $\left(20-60^{\circ} \mathrm{C}\right)$ by maintaining a constant initial concentration of phenol (14 mg/L). For this purpose, $1 \mathrm{~g}$ of activated carbons was added to the phenol solution. The samples were shaken for 120 minutes. 


\section{RESULT AND DISCUSSION}

\subsection{Effect of Contact Time}

Effect of contact time on adsorption of phenolic compounds by banana peel cactus are presented in Fig 1. The result showed that the removel efficiency increased with increasing soaking time. Initially, adsorption increased sharply and slowed gradually until equilibrium was attained in approximately $3 \mathrm{~h}$. Almost, no remarkable improvement was observed after longer contact time. This observation was attributed to the availability of readily accessible sites during the initial stage, and the remaining vacant surface sites were difficult to be occupied due to the repulsive forces between the solute molecules on the solid and bulk phases, as the equilibrium approached. The time required to attain this state of equilibrium is termed as equilibrium time.

The contact time required for the phenol to reach to the equilibrium was relatively short. This finding indicated the economical availability for the real practical applications.

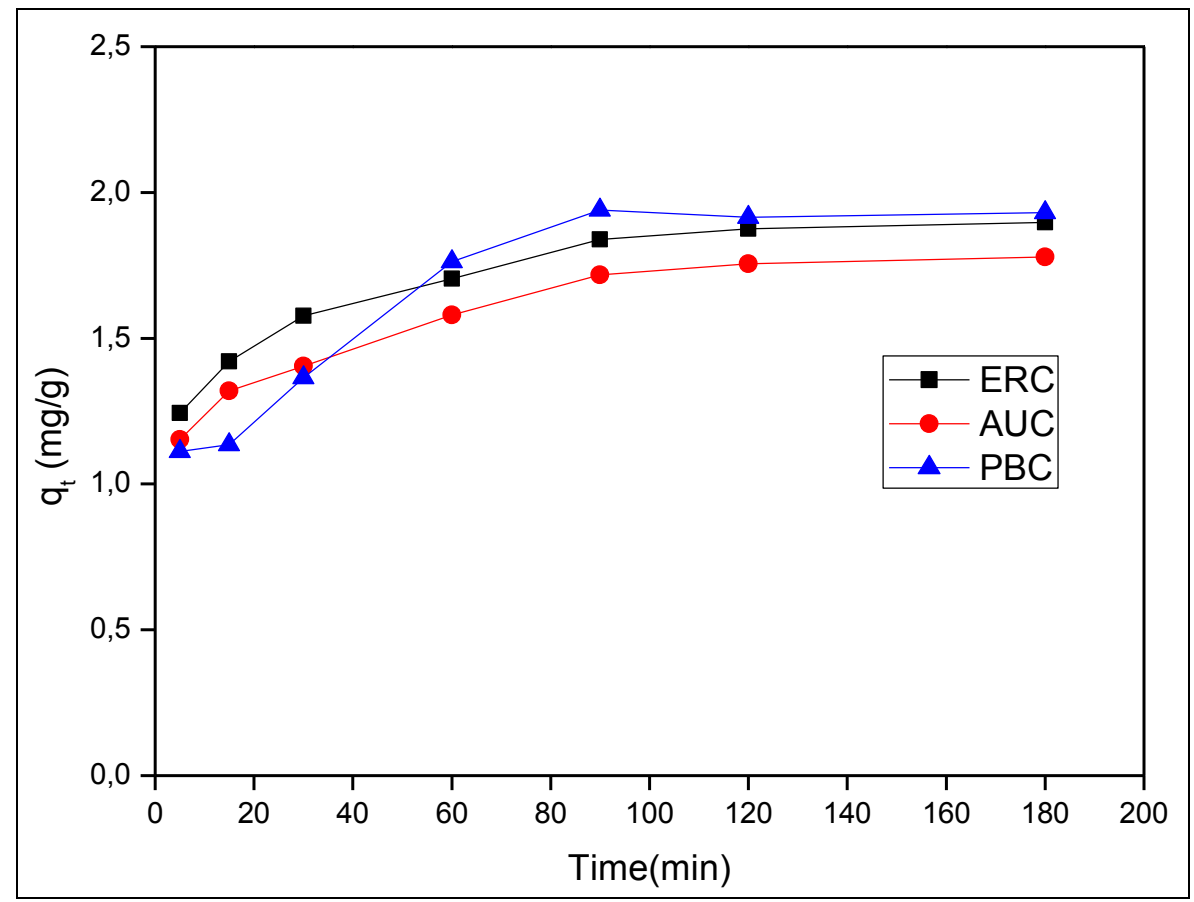

Figure 1: Effect of contact time.

$\mathrm{C}_{0}=14 \mathrm{mg} / \mathrm{L}, \mathrm{m}=1 \mathrm{~g}, \mathrm{~V}=100 \mathrm{~mL}, \mathrm{pH}=6.8, \mathrm{~T}=25^{\circ} \mathrm{C}$

Adsorption rate of phenol on cactus and banana charbons was found to be relatively much faster than those reported for some other normal adsorbents. Xiaolo and Youcai, (2006) investigated the adsorption of phenolic pollutants in the aqueous solution by aged-refuse, and reported that the remaining concentration of the phenolic pollutants in the liquid phase becomes asymptotic to the time axis after $4 \mathrm{~h}$ of shaking. Usarat and Pakulanon (2007) determined that the sorption equilibrium of phenol on dried sewage sludge was reached within 20h. Adsorption of bromophenols onto carbonaceous adsorbents derived from fertilizer solid waste was performed by Bhatnagar (2007) and reported an equilibrium time of about 8h. However, El Gaidoumi et al. (2015) in their study on Phenol Adsorption by a Moroccan Pyrophyllite, indicated a 25 min equilibrium time. The comparison of the three characters makes it easy to conclude that PBC has an adsorbent capacity greater than the AUC but normative at the ERC.

\subsection{Effect of adsorbent dosage}

Figure 2 shows that the adsorption capacity was found to be high at low doses. This decrease in adsorption capacity with the increase in the adsorbent dosage is mainly attributed to the unsaturation of the adsorption site during the adsorption process (Han and $a l .$, 2006). The same results were obtained by achak et al. (2009) in the study of the adsorption of banana peel for the removal of phenolic compound from olive mill wastewater. 


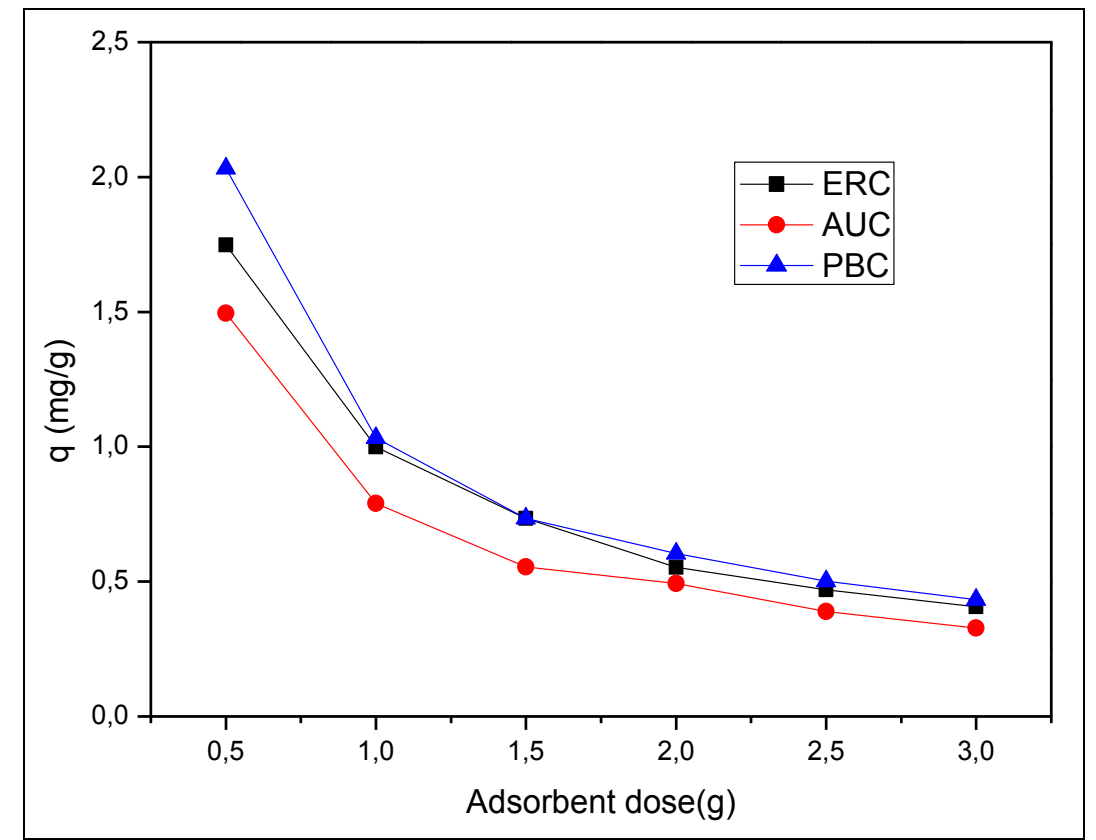

Figure 2: Effect of adsorbent dosage

$\mathrm{C}_{0}=14 \mathrm{mg} / \mathrm{L}, \mathrm{V}=100 \mathrm{~mL}, \mathrm{pH}=6.8, \mathrm{t}=120 \mathrm{~min}, \mathrm{~T}=25^{\circ} \mathrm{C}$

\subsection{Effect of $\mathrm{pH}$ on phenol biosorption}

The most important parameter influencing the adsorption capacity is the $\mathrm{pH}$ of adsorption medium (Goyal and al., 2003). The $\mathrm{pH}$ affects the adsorption mechanisms on the adsorbent surface and influences the nature of the physic-chemical interactions of the species in solution and the adsorptive sites of adsorbents (Zumrize and Yener, 2001). The effect of pH on the adsorption of phenol by charbons (cactus, banana peel) at $\mathrm{pH}$ ranging between 2 and 12 is shown in Fig 3. There is a considerable decrease in the adsorption capacity of phenol in the $\mathrm{pH}$ range studied. Similar results have been obtained by Usarat and Pakulanon, (2007), which studies the adsorption of phenols on dried sludge. They reported a decrease in phenol adsorption at higher pH. Many other authors with similar behavior indicated a change in the surface charge of the adsorbent. Indeed, as the pH of the medium increases, the number of negatively charged sites increases, this should be less favorable to the adsorption of negatively charged phenolate ions and the surface of the positively charged adsorbent due to electrostatic repulsion. (Namasivayam and Kavitha, 2002, Fu and Viraraghavan, 2002).

On the other hand, in other studies, we can find appreciable adsorption rates at alkaline pH. The work of Achak and al. (2009) on the removal of phenolic compounds from banana peel has shown that an increase in $\mathrm{pH}$ to $(\mathrm{pH} 7-11)$ results in an increase in adsorption capacity.

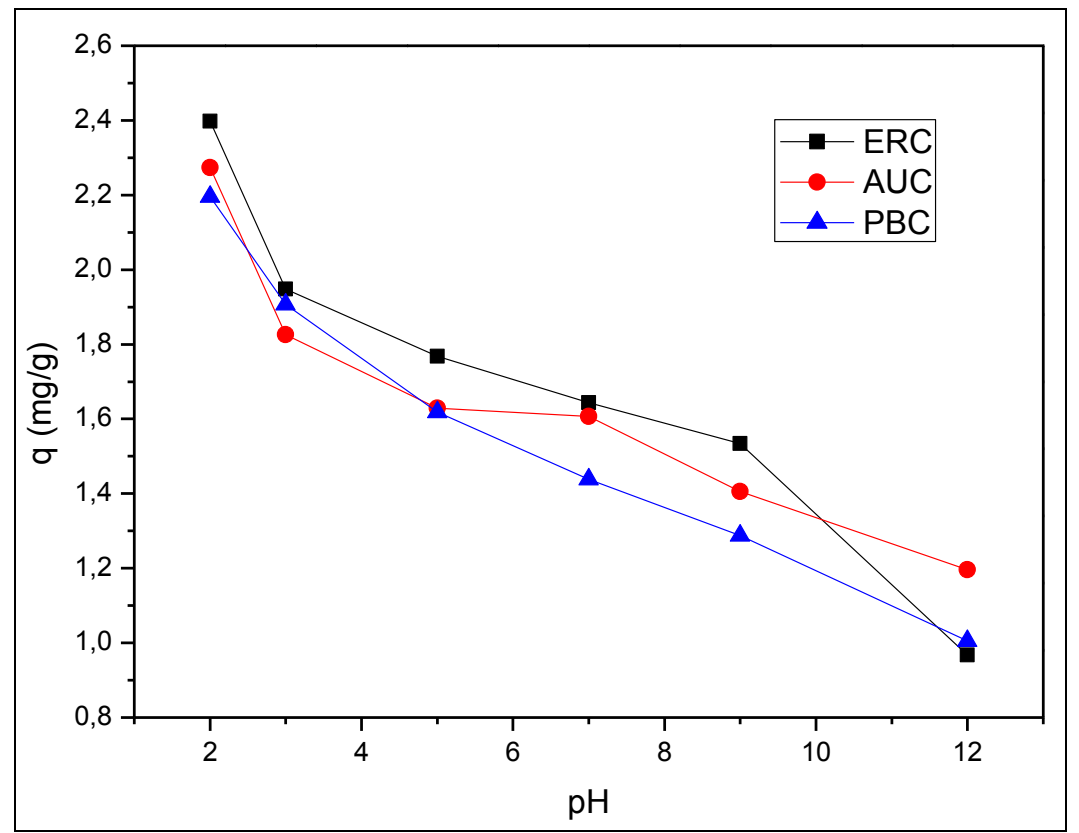

Figure 3: Effect of Solution $\mathrm{pH}$.

$\mathrm{C}_{0}=14 \mathrm{mg} / \mathrm{L}, \mathrm{m}=1 \mathrm{~g}, \mathrm{~V}=100 \mathrm{~mL}, \mathrm{t}=90 \mathrm{~min}, \mathrm{~T}=25^{\circ} \mathrm{C}$ 


\subsection{Effect of initial phenol concentrations}

The concentration effect was evaluated as one of the most important factors affecting adsorption.

Figure 4 shows the effect of the concentration on phenol adsorption of cactus and banana peels. These results show that the adsorption is considerably improved by increasing the phenol concentration. This is related to an increase in the driving force of the concentration gradient to overcome the mass transfer resistance between the aqueous phase and the solid phase.

The maximum adsorption was determined, in addition these results shows ERC is a better absorption of phenol than other coals.

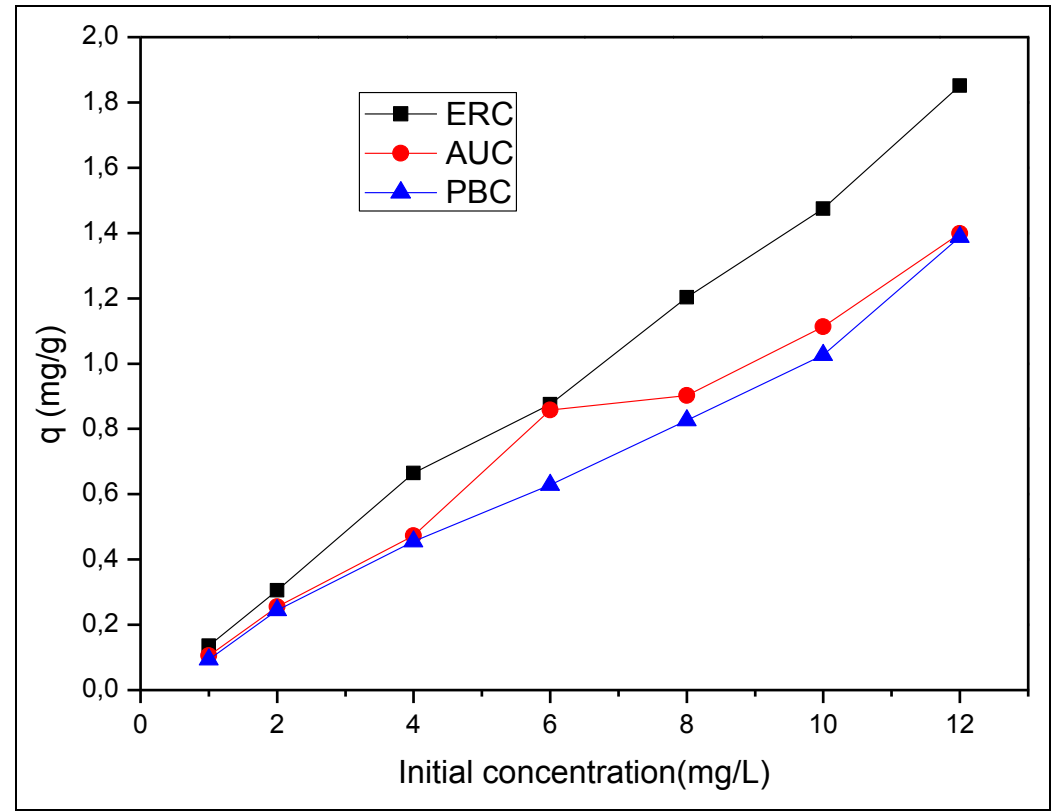

Figure 4: Effect of initial phenol concentrations.

$\mathrm{m}=1 \mathrm{~g}, \mathrm{~V}=100 \mathrm{~mL}, \mathrm{pH}=6.8, \mathrm{t}=90 \mathrm{~min}, \mathrm{~T}=25^{\circ} \mathrm{C}$

\subsection{Effect of temperature}

The performance of sorbents under different reaction temperature was studied. Fig 5 shows the removal of phenol as a function of solution temperature in an aqueous solution of $\mathrm{pH}=6.8$. The initial phenol concentration is $14 \mathrm{mg} / \mathrm{L}$ and adsorbent dosage is $1 \mathrm{~g}$. With varying the temperature of phenol solution from 20 to $60{ }^{\circ} \mathrm{C}$. The sorption efficiency is enhaced by increasing the temperature from 20 to $50^{\circ} \mathrm{C}$. The observed enhanced in sorption capacity might be explained in the base the of chemical adsorbate-adsorbent interaction leading to creation of new adsorption sites. These interactions can produce an increase in the rate of intra-particule diffusion of phenol ions into the charbon at higher temperature.

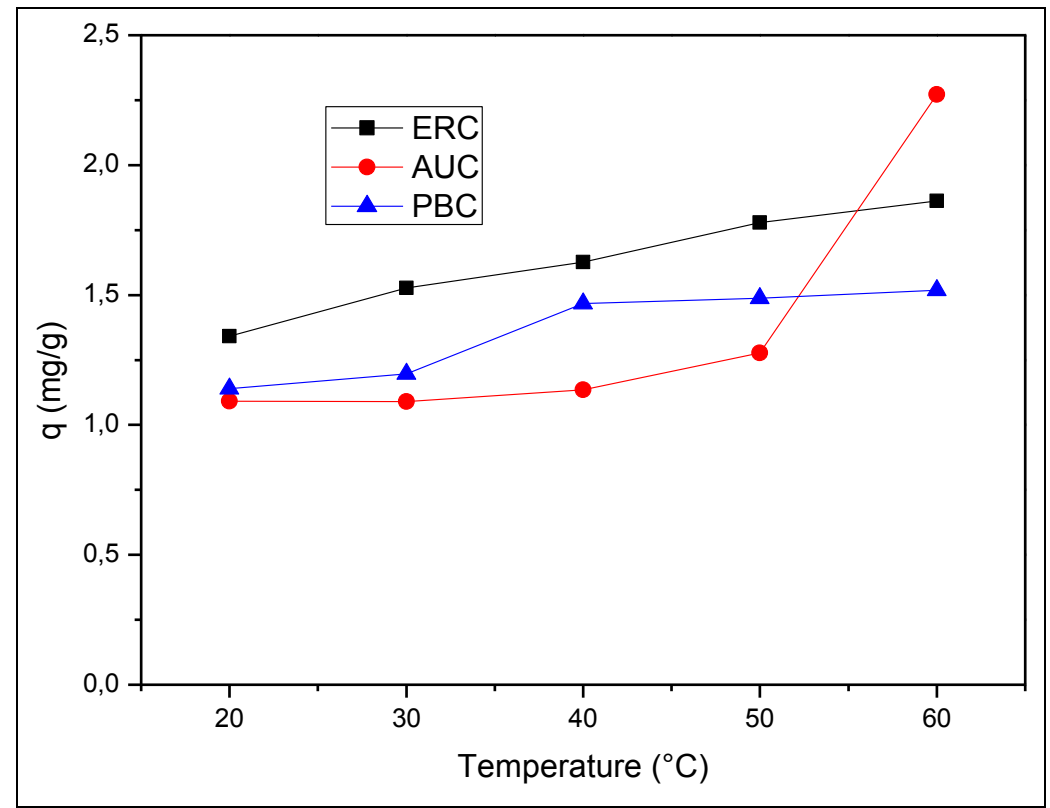

Figure 51: Effect of Temperature.

$\mathrm{C}_{0}=14 \mathrm{mg} / \mathrm{L}, \mathrm{m}=1 \mathrm{~g}, \mathrm{~V}=100 \mathrm{~mL}, \mathrm{pH}=6.8, \mathrm{t}=90 \mathrm{~min}$ 
Citation: Tossou Germain, et al., Adsorption of Phenol on Carbon Based on Cactus and Banana Peel. Australian Journal of Basic and Applied Sciences, 13(1): 64-70. DOI: 10.22587/ajbas.2019.13.1.8

\section{CONCLUSION}

The results obtained in batch adsorption of phenol on cactus-based coals (ERC, AUC) and banana peels (PBC) have shown that the adsorption of phenol is possible by these materials. The best adsorption has been found to be preferential for ERC. The study shows that the physicochemical parameters have a considerable effect on the adsorption of phenol on coals from biomass; in fact, adsorption increases with increasing $\mathrm{pH}$, concentration, and temperature. In addition, this study showed that the adsorption increases with time until the adsorption equilibrium is reached after 90 minutes. On the other hand, the study of the effect of the adsorbent dose shows that the adsorption of phenol decreases as the amount of adsorbent increases.

\section{REFERENCES}

Achak, M., A. Hafidib, N. Ouazzania, S. Sayadic, and L. Mandia, 2009. Low cost biosorbent "banana peel" for the removal of phenolic compounds from olive mill wastewater: Kinetic and equilibrium studies. Journal of Hazardous Materials, 166: 117125. doi.org/10.1016/j.jhazmat.2008.11.036

Acosta, C.A., P.C.E. López, G. Paniagua, R. M. Garcinuño, and H.P. Fernández, 2018. Evaluation of total phenol pollution in water of San Martin Canal from Santiago del Estero, Argentina. Environmental Pollution, 236: $265-272$. doi.org/10.1016/j.envpol.2018.01.062

Al-Muhtase, A.H., K.A. Ibrahim, A.B. Albadarin, O. Ali-khashman, G.M. Walker, and M.N.M. Ahmad, 2011. Remediation of phenol-contaminated water by adsorption using poly (methyl methacrylate) (PMMA). Chem. Eng. J., 168: 691-699. doi.org/10.1016/j.cej.2011.01.057

Álvarez-Torrellas, S., M. Martin-Martinez, H.T. Gomes, G. Ovejeroa and J. Garcíaa, 2017. Enhancement of p-nitrophenol adsorption capacity through N2-thermal-based treatment of activated carbons. Applied Surface Science, 414: $424-434$. doi.org/10.1016/j.apsusc.2017.04.054

Arba, M., E.L. Aich, A. Sarti, B. Belbahri, L.L. Boubkraoui, A. Ait Hammou, A. Zemmouri, and A.H. Sbass, 2000. Valorisation du figuier de babarie en élevage. Bull. Men Inf et de liaison du PNTTA, 68 :1-4.

ATSDR (Agency for Toxic Substances and Disease Registry), 2007. Notice of the revised priority list of hazardous substances that will be the subject of toxicological profiles.

Banasiak, L.J., B. Van der Bruggen, and A.I. Schafer, 2011. Sorption of pesticide endosulfan by electrodialysis membranes. Chem. Eng. J., 166: 233-239. doi.org/10.1016/j.cej.2010.10.066

Bhatnagar, A., 2007. Removal of bromophenols from water using industrial wastes as low cost adsorbents. J. Hazard. Mater., 139 : 93-102. doi.org/10.1016/j.jhazmat.2006.06.139

Boujghagh, M., and L. Chajia, 2001. Le cactus: outil de gestion de la sécheresse dans le sud marocain. Terre et Vie, 52:1 - 7.

Chandana, L.M.V., and V. Sridevi, 2009. Review on biodegradation of phenol from industrial effluents. Jr. of Industrial Pollution Control, 25(1) :13-27.

de Souza, M.T.F., E. Ambrosio, C.A. de Almeida, T.K.F. Souza Freitas, L.B. Santos, V. de Cinque Almeida, and J.C. Garcia, 2014. The use of a natural coagulant (Opuntia ficus-indica) in the removal for organic materials of textile effluents. Environ Monit Assess, 186:5261-5271. doi.org/10.1016/j.jtice.2016.07.009

Duan, W., F. Meng, H. Cui, Y. Lin, G. Wang, and J. Wu, 2018. Ecotoxicity of phenol and cresols to aquatic organisms. Ecotoxicology and Environmental Safety, 157: 441-456. doi.org/10.1016/j.ecoenv.2018.03.089

El Gaidoumi, A., A.B. Chaouni, A. Lahrichi, and A. Kherbeche, 2015. Adsorption du Phénol en Milieu Aqueux par une Pyrophyllite Marocaine Brute et Traitée. J. Mater. Environ. Sci., 6(8) 2247-2259.

Fu, Y., and T., Viraraghavan, 2002. Removal of Congo Red from an aqueous solution by fungus Aspergillus niger. Advances in Environmental Research, 7:239-247. doi.org/10.1016/S1093-0191(01)00123-X

Goyal, N., S.C. Jain, and U.C. Banerjee, 2003. Comparative studies on the microbial adsorption of heavy metals. Advances in Environmental Research, 7: 311-319. doi.org/10.1016/S1093-0191(02)00004-7

Habibi, Y., 2004. Contribution à l'étude morphologique, ultrastructurale et chimique de la figue de barbarie. Les polysaccharides pariétaux: charactérisation et modification chimique. Thèse de Doctorat, Université Joseph Fourier, Grenoble, France.

Han, R.P., W.H. Zou, J. Shi, and J.J. Yang, 2006. Removel of copper (II) and lead II from aqueous solution by manganese oxide coated sand. I; characterization and kinetic study. J. hazard mater, 137:384-395. doi:10.1016/j.seppur.2007.07.006

Lv, J., W. Gong, H. Kai, J. Zhu, F. Meng, X. Song, and Z. Sun, 2011. Effect of annealing temperature on photocatalytic activity of $\mathrm{ZnO}$ thin films prepared by sol gel method. Superlattices and Microstructures, 2: 98-106. doi.org/10.1016/j.spmi.2011.05.003

Maldonado, M.I., S. Malato, L.A. Perez-Estrada, W. Gernjak, I. Oller, X. Domenech, and J. Peral, 2006. Partial degradation of five pesticides and an industrial pollutant by ozonation in a pilot-plant scale reactor. J Hazard Mater., B138:363-369. doi.org/10.1016/j.jhazmat.2006.05.058

Matta, R., K. Hanna, and S. Chiron, 2008. Oxidation of phenol by green rust and hydrogen peroxide at neutral pH .Separation and Purification Technology, 61(3): 442-446. doi.org/10.1016/j.seppur.2007.12.005

Mohamed, A.R., M. Mohammadi, and G. N. Darzi, 2010. Preparation of carbon molecular sieve from lignocellulosic biomass. Renewable and Sustainable Energy Reviews, 14:1591-1599. doi.org/10.1016/j.rser.2010.01.024

Moussavi, G., M. Mahmoudi, and B., Barikbin, 2009. Biological removal of phenol from strong wastewaters using a novel MSBR. Water Research, 43(5): 1295-1302. doi.org/10.1016/j.watres.2008.12.026

Namasivayam, C., and D., Kavitha1, 2002. Removal of Congo Red from water by adsorption onto activated carbon prepared from coir pith, an agricultural solid waste. Dyes and Pigments, 54: 47-58. doi.org/10.1016/S0143-7208(02)00025-6 
Pan, G., and K-I., Kurumada, 2008. Hybrid gel reinforced with coating layer for removal of phenol from aqueous solution. Chemical Engineering Journal, 138(1-3): 194-199. doi.org/10.1016/j.cej.2007.06.025

Pourata, R., A.R. Khataee, S. Aber, and N., Daneshvar, 2009. Removal of the herbicide bentazon from contaminated water in the presence of synthesized nanocrystalline $\mathrm{TiO}_{2}$ powders under irradiation of UV-C light. Desalination, 249: $301-307$. doi.org/10.1016/j.desal.2008.10.033

Ry, S. and T. Murugesan, 2002. Studies on biodegradation of phenol using response surface methodology. Journal of Chemical Technology and Biotechnology, 77: 1219 -1230. DOI: 10.1002/jctb.692

Usarat, T., and K. Pakulanon, 2007. Bioresource Application of dried sewage sludge as phenol biosorbant. Bioresource Technology, 98:140-144. DOI:10.1016/j.biortech.2005.11.004

Xiaolo, C., and Z.Youcai, 2006. Adsorption of phenolic compound by aged-refuse. Journal of Hazardous Materials, B137: 410417. doi.org/10.1016/j.jhazmat.2006.02.015

Zumrize, A. and J. Yener, 2001. A Comparative Adsorption/ Biosorption Study Of Mono-Chlorinated Phenols Onto Various Sorbents. Waste Management, 21: 695-702. doi.org/10.1016/S0956-053X (01)00006-X 